\title{
POLITYCE JEST POTRZEBNY DOBRY PIAR
}

W spółczesna rzeczywistość chyba się trochę pogmatwała i wygląda na to, że człowiek znalazł się w komunikacyjnej pułapce. $Z$ różnych stron dociera tak wiele komunikatów i przekazów, że prawdopodobnie nieliczni zachowuja zdrowe spojrzenie na swoje życie. $\mathrm{Na}$ każdym kroku dopada człowieka reklama, media, czyli trochę wykreowana przez wielkiego brata fikcja. Wraca do domu, wysiada ze swojego nowiutkiego, nigdy nie psującego się samochodu, wita go szeroko uśmiechnięta żona, która serwuje obiad według najlepszej receptury telewizyjnego guru od kuchni. Dom wypełniaja głosy dzieci z białymi ząbkami i ślicznymi Barbie. Wieczorem rodzina siada przed telewizorem i popijają wyborna angielską herbatkę z promocyjnych kubków, zastanawiają się czy na pewno mają wszystko to, czego potrzebuja. W tym samym czasie twórca reklamy albo producent jakiegoś gadżetu reklamowego obmyśla kolejną strategię, która pozwoli mu podbić rynek i uszczęśliwić kolejną rodzinę Kowalskich, która niczego nie podejrzewajacc, ulegnie po raz kolejny i jutro kupi reklamowany dziś proszek do prania albo gumę do żucia.

Z dnia na dzień, z godziny na godzinę, nieustannie cywilizacja kroczy do przodu, nauka rozwija się w zawrotnym tempie również po to, aby znaleźć nowy sposób dotarcia do człowieka. Kolejny sposób komunikacji, komunikacji na ogromną skalę, bo kiedy żyje się już w globalnej wsi, to nic nie zna granic, tym bardziej komunikacja, która korzysta z najnowszych mediów i wynalazków.

Jakieś dziesięć może piętnaście lat temu niewielu było ludzi w Polsce, którzy dobrze znaliby nowoczesne środki i metody komunikacji tak dobrze jak na przykład Amerykanie. Przełom roku 1989 przyniósł 
zmiany również $\mathrm{w}$ dziedzinie komunikacji i mediów. Polacy zaczęli poznawać, co to reklama, promocja, sponsoring, lobbing czy public relations. No właśnie piar inaczej public relations - do tego zmierzam. Sądzę, że także dziś są jeszcze osoby, które nie wiedzą cóż to jest PR, nie wiedzą, iż jest to forma współczesnego komunikowania się ${ }^{1}$.

Zacznę może krótko od tego, czym właściwie jest public relations i czemu ma służyć. Trudno jest podać jedną zasadniczą definicję terminu, bowiem często, ilu badaczy, tyle definicji problemu. Już w połowie XX wieku w USA, w kraju, w którym narodził się piar było około 980 definicji $^{2}$, a od tego czasu pojawiło się wiele nowych aspektów PR, ze względu, na które można formułować kolejne. Obecnie jest ich ok. 2000 tysięcy na całym świecie. W nowe definicje swój wkład mają również polscy badacze, a wśród nich Tomasz Goban-Klas, dla którego PR to promocja reputacji poprzez nawiązywanie i podtrzymywanie wzajemnie korzystnych stosunków pomiędzy instytucją i grupami opinii publicznej, od których zależy jej sukces lub klęska ${ }^{3}$. Natomiast Paweł Czarnowski postrzega PR jako uczciwą i obiektywna, fachową i kompetentna, pełną i szybką, przyjemną dla mediów i opinii publicznej, odpowiedzialna informację. Myślę, że można jeszcze przywoływać wiele innych sformułowań na ten temat, jednak, aby zrozumieć PR trzeba to zrobić w nieco prostszy sposób. Opisać to tak: za działanie public relations uznaje się świadome, zaplanowane i długotrwałe pielęgnowanie stosunków jakiejkolwiek organizacji, zarówno gospodarczej, niegospodarczej jak i instytucji publicznej czy urzędu, bądź indywidualnego człowieka z bliższym lub dalszym otoczeniem zwanym public, publicity. ${ }^{5}$ Przy uwzględnieniu nastawienia i opinii oraz zainteresowania publiczności względem w/w organizacji, które poznawane są za pośrednictwem systemu informatycznego, bądź zwrotnego sygnału. Działalność ta ma służyć wzbudzeniu zainteresowania i sympatii lub/i pozytywnego nastawienia oraz wzrostowi zaufania wobec organizacji. Zaś krótko mówiąc PR to także permanentna sztuka mówienia (prawdy) i robienia tego, co spowoduje, że ludzie będą mieli dobre zdanie o „firmie”.

\footnotetext{
${ }^{1} \mathrm{Na}$ ten temat zobacz: B. Sobkowiak, Public relationis jako forma komunikowania masowego, w: Studia z teorii komunikowania masowego, pod red. B. Dobek-Ostrowskiej, Wrocław 1999; A. Augustyn, Public relations jako instrument komunikacji marketingowej, „Optimum”, 2003, nr 1, s. 105-118.

${ }^{2}$ K. Wojcik, Public Relations od A do Z, Warszawa 2001, s. 19.

3 T. Goban-Klas, Public Relations, czyli promocja reputacji, Warszawa 1997, s. 12 i n.

${ }^{4}$ Http:www.piar.pl.

${ }^{5}$ K. Wojcik, dz. cyt., s. 51-54.
} 
Obecnie ma miejsce taka sytuacja, że piar wkracza praktycznie w każdą dziedzinę naszego życia, a dzieje się to mniej lub bardziej świadomie. Czasem najdziwniejsze rzeczy, najmniej spodziewane sytuacje czy podmioty stają się towarem na „marketingowym” rynku, a tym samym obiektem zainteresowań PR i to z tej perspektywy, że okazuje się nieodzowne mieć świetnie zorganizowany piar, gdyż bez niego bardzo trudno jest sprzedać owy towar i funkcjonować w codziennej rzeczywistości. Konieczne po prostu jest posługiwanie się niekiedy mało znanym narzędziem, formą komunikacji, jaką bez wątpienia jest public relations.

Towarem, który musi się dobrze sprzedać jest, już od jakiegoś czasu, szeroko rozumiana polityka i politycy, a także sam proces legitymizacji demokratycznych władz i instytucji publicznych. Uważam, że tej sferze ludzkiej egzystencji bardzo potrzebny jest piar, dobry i rzetelny sposób promowania społeczeństwa obywatelskiego. Warto podkreślić na wstępie, że bez zrozumienia i poparcia otoczenia niemożliwe byłoby przynajmniej w społeczeństwach demokratycznych i konkurencyjnych gospodarkach wolnorynkowych trwałe prowadzenie jakiegokolwiek typu organizacji.

Ale po kolei, zacznę od tego, że współczesny bomo politicus jest bardzo leniwy i potrzebuje wielu silnych bodźców by wykazać jakąkolwiek aktywność w sferze polityki i obowiązków względem wspólnoty - narodu, którego jest ważną częścią.

Wybory to święto demokracji ${ }^{6}$, w czasie którego najważniejszy jest wyborca, a nie partie czy politycy. Jest to czas, który powinien dawać poczucie wspólnoty i udziału w zarządzaniu własnym państwem przez każdego z obywateli. Dlaczego tak nie jest? Sądzę, że jednym z priorytetowych powodów jest brak odpowiedniej promocji tej zasadniczej instytucji demokratycznego państwa. Brak informacji i edukacji o jej znaczeniu, funkcjach i korzyściach, jakie może przynosić jej sprawne działanie. Właśnie na tym etapie konieczna jest działalność public relations. Może to trochę utopijna koncepcja, jednak myślę, że potrzebna i korzystna. Zapewne są ludzie, którzy maja świadomość tego jak wiele można w ten sposób zdziałać, choćby stosując odpowiednia długotrwała i rzetelna akcję informacyjną na temat wyborów i szans, jakie ze sobą niosa. Trzeba przełamać stereotyp, że nauka postaw obywatelskich to propaganda rządzących, przygotowując solidny program edukacyjny, który pozwoli poczuć przyszłym wyborcom, że ich

${ }^{6}$ Kampania wyborcza. Strategia-taktyka-komunikacja, pod red. S. Wilkosa i W. Ferenca, Warszawa 2001, s. 5 i n. 
zachowanie i postawa sa podstawowym elementem na drodze do zdrowej demokracji.

Stosując zasady i sposoby PR warto by prowadzić kampanie na rzecz obywatelskiej postawy nie tylko w przeddzień wyborów, ale permanentnie, choćby odwołując się do Amerykańskich wzorców GOTV, czyli get out to vote, a więc „idź i głosuj”” i szukając nowych polskich pomysłów i rozwiązań.

Uważam, że oczywiste jest, jak znaczącym argumentem, popierającym potrzebę dobrego piaru w sferze polityki są korzyści, które mogą przynieść i przynoszą $w$ innych krajach, działania promujące fundamentalną instytucje demokracji. Rzec możnaby, że to nie tylko zwykły piar, to po prostu budowa świadomego społeczeństwa obywatelskiego.

Myślę, że równie ważnym argumentem, dającym poparcie mojej tezie, jest stan relacji między różnego rodzaju urzędami publicznymi, a ich petentami. Pracę i sposób podejścia administracji publicznej do obywatela można często ocenić bardzo źle, wręcz fatalnie. Wynika to z braku odpowiedniego zarządzania, świadomości i przygotowania urzędników, a także właściwej komunikacji, czyli właściwego PR. W wielu krajach działalność informacyjna państwa, dialog i współpraca ze społeczeństwem podlega kontroli, odpowiednim przepisom prawa i kodeksom etycznym. Także z zakresu uregulowań prawnych public relations. W Polsce sprawa jest o tyle skomplikowana, że nie istnieja konkretne, jednolite przepisy dotyczace samego PR, jego funkcjonowania na gruncie mu bliższym, czyli w dziedzinie gospodarki, marketingu itp. ${ }^{8}$, a co dopiero w sferze administracji publicznej czy polityki. Kontynuując jednak wątek: w potrzebie zastosowania piaru w polskiej administracji publicznej najistotniejsze jest to, jakie niezbędne dla obu stron, cele można przy jego użyciu zrealizować. Jest to przede wszystkim stworzenie kanału, sposobu porozumiewania się administracji, urzędu z obywatelem, lokalnym biznesem czy inwestorem. Ponadto celem PR w urzędzie jest informowanie społeczeństwa o sprawach, w których kompetentny jest urząd, uczynienie jasnym i klarownym systemu działania administracji i państwa na rzecz społeczeństwa i jego podmiotów. A także zgoda na uczestnictwo w usprawnianiu sfery publicznej poprzez gromadzenie i uwzględnianie opinii, sugestii i oczekiwań względem działania i kooperacji instytucji i obywateli.

${ }^{7}$ Tamże, s. 107.

${ }^{8} \mathrm{Na}$ temat prawnych aspektów PR w RP zobacz: A. M. Dereń, Prawne uwarunkowania public relations w Polsce, Bydgoszcz 1999.

${ }^{9}$ K. Wojcik, dz. cyt., s. 776. 
Realizacja zaledwie tych kilku celów pozwoliłaby, oczywiście nie z dnia na dzień, ale w dłuższej perspektywie, uzyskać zaufanie obywateli, klientów i rozmaitych reprezentacji społecznych czy liderów opinii. A także pozyskać zrozumienie dla sposobu działania i podejmowania decyzji w administracji oraz dostrzec kompetencje, indywidualną pracę i starania osób pełniących funkcje kierownicze. Działalność PR daje również możliwość oceny funkcjonowania administracji, weryfikacji jej sprawności przez pryzmat postulatów i interesów poszczególnych osób, petentów i innych biorących udział w życiu danej społeczności lokalnej. Budowa dobrego wizerunku urzędu, to nie tylko usprawnienie komunikacji, to również łatwość dochodzenia do konsensusu między nim, a jego klientem. Za pomoca uprzedniej fachowej informacji związanej z podejmowaną decyzja, bieżącą pracą oraz planami na przyszłość i stosunkiem do problemów życia społeczno-gospodarczego, praw i obowiązków obywateli ${ }^{10}$. Należy ponadto podkreślić, że public relations $\mathrm{w}$ administracji publicznej musi być skierowane zarówno do wewnątrz, jak i na zewnątrz. Stąd wynika, że otoczenie, do którego kieruje się działania jest duże i zróżnicowane, dlatego komunikacja z nim powinna być odpowiednio dostosowana. $Z$ reguly wykorzystuje się do tego bezpośredni kontakt, osobowy lub nieosobowy oraz środki masowej komunikacji. Sa to odpowiednio spotkania z mieszkańcami, punkty konsultacyjne i doradcze, biura skarg i wniosków, a także ogłoszenia, broszury, ulotki, dodatki do gazet, sprawozdania i listy do obywateli oraz programy $\mathrm{w}$ radio lub telewizji. Istotną rolę $\mathrm{w}$ komunikacji spełniają również badania opinii społecznej ${ }^{11}$. Specjaliści od PR urzędu, tj. Stany Zjednoczone i Wielka Brytania, rozwijają tę dziedzinę cały czas w zawrotnym tempie, znajduja nowe rozwiązania i zaskakuja pomysłami. Warto mieć nadzieję, że wkrótce i w Polsce dostrzeżona zostanie wartość zastosowania piaru w administracji publicznej. Oby były to działania prowadzone w odpowiednim czasie (nasza administracja już pilnie potrzebuje takich działań), a nie dopiero wtedy, gdy nadchodzi kryzys, który wzbudza niechęć i krytykę obywateli. $\mathrm{Na}$ przykład w telewizji regionalnej lub radiu zaczną pojawiać się programy, które będa „organizować kontakty” społeczeństwa i władz, miast będą produkować filmy dokumentalne o pracy swych organów, a drzwi urzędów będą często „otwarte”.

Zasadnicze znaczenie dla sfer polityki i zarządzania państwem maja konkretni ludzie, politycy i partie polityczne. Właśnie im najbardziej

10 Tamże, s. 777 i n.

${ }^{11}$ Http:www.pressence.com.pl. 
niezbędny jest poprawny piar, potrzebny zarówno z perspektywy ich samych, jak i wyborców.

Wyborca, obywatel ma pełne prawo do tego, by móc poznać rządzących i innych polityków nie tylko w krótkim czasie kampanii wyborczej, ale dużo wcześniej. Dlatego, spoglądając z jego strony, konieczne jest solidne i prawdziwe odsłanianie twarzy polityków i kulis polityki. Obywatel nie musi poznawać tajemnic państwowych, wystarczy, gdy będzie miał łatwy dostęp na przykład do publikacji ustaw, rozporządzeń itp., zafunduje mu się zastrzyk informacji w postaci broszury, ogłoszenia ulotki czy sprawozdania ${ }^{12}$ (w ciekawej postaci oczywiście) na temat tego, co, kiedy i gdzie robi lub zrobił Prezydent, Premier czy poseł z okręgu.

Zaś patrząc z przeciwnej strony, tzn. ze strony polityka, wydaje się iż powinno być oczywiste, że bez public relations ani rusz jeśli chce się pozostać u władzy. Również z tej perspektywy obowiązuje zasada, że czas kampanii to zdecydowanie za krótko by zdobyć zaufanie i głosy obywateli, a przecież właśnie o to chodzi.

Polityk ma w tej kwestii szerokie pole manewru, przed wszystkim stać go na to, żeby zatrudnić fachowca od PR. Ponadto będąc już parlamentarzysta ma łatwy dostęp do mediów. Wystarczy tylko, aby zachowywał się interesująco. W tej materii jedni obierają droge skandali, inni kreują się na mężów stanu, jeszcze inni w ogóle nie mają na siebie pomysłu. Co może stanowić źródło problemów, gdyż polityk powinien mieć określoną wizję w stosunku do siebie i swoich działań politycznych $^{13}$, a w jej realizację winien być zaangażowany piar. Jak już wspomniałam rzetelna i prawdziwa informacja, jasny i przejrzysty obraz działania polityka, który buduje wiarygodność i budzi sympatię elektoratu to podstawa ${ }^{14}$. Jednak często bywa i tak, że nie jest możliwe budowanie wizerunku i zaufania wobec polityka w oparciu o prawdę itp., gdyż jego ręce i sumienie nie sa czyste. W takich sytuacjach na arenę wkraczaja często tzw. spin doctors ${ }^{15}$. Sa to osoby świetnie znające metody PR, jednak działające $w$ oparciu i przy zdecydowanym udziale kłamstw lub „upiększonej” prawdy na temat danego polityka. Robią oni wszystko, aby osiagnąć cel tzn. wykreować taką postać - polityka, który będzie popularny, medialny i wygra kolejne wybory. Jest to w pewien sposób

\footnotetext{
${ }^{12}$ Http:www.piar.pl.

13 Porównaj na ten temat: A. Riklin, Niccolo Machiavellego nauka o rzqdzeniu, Poznań 2000.

${ }^{14}$ Http:www.pressence.com.pl.

15 J. Olędzki, Public relations - sz̨tuka budowania zaufania, „Studia Medioznawcze”, 2002, nr 3 , s. 12 i n.
} 
realizacja społecznego zapotrzebowana na określony produkt, na określonego polityka, który najlepiej się sprzeda.

Zarówno w Polsce, jak i na całym świecie trudno jest zdemaskować czarny piar, nie ulega jednak wątpliwości, że ma on miejsce. Dla pocieszenia strapionych warto mieć na uwadze to, że podobno kłamstwo zawsze wychodzi na jaw.

Istnieje szereg działań zgodnych z etyką, które może podjąć polityk, chcąc promować swoją wizję państwa, reputację czy tożsamość. Może on utrzymywać stały kontakt ze swoimi wyborcami w sposób bezpośredni spotkania z mieszkańcami okręgu, w którym został wybrany, udział w imprezach i akcjach społecznych oraz pośredni - sprawozdania, broszurki, mailing, stosowany w czasie kampanii wyborczej ,door to door ${ }^{216}$, w którą zaangażowani są na przykład wolontariusze, będący zwolennikami kandydata i inne metody. Jak wcześniej pisałam, dostęp do mediów jest znaczacy w przypadku posła lub senatora, wystarczy tylko odpowiednio wykorzystać zaproszenia do debat czy programów publicystycznych i zaprezentować się $\mathrm{w}$ nich poprawnie, zgodnie ze swoją wizją. W przypadku polityka, któremu nieco brak ogłady lub, który jest nadpobudliwy nieodzowne jest przygotowanie do wystapień publicznych, zarówno pod względem merytorycznym (to dotyczy wszystkich), jak i dykcji, sposobu bycia itp. Nie może to jednak być wyreżyserowane przedstawienie, lecz kilka wskazówek doświadczonego doradcy politycznego czy medialnego ${ }^{17}$. Warto w tym miejscu zauważyć, że potrzeba piaru w polityce rodzi perspektywy rozwoju dla politologów, którzy moga zdobywać nowy rynek pracy, gdyż wydaje się, że zapotrzebowanie na w/w doradców wzrasta, choć niestety oznacza to w jakimś stopniu, iż poziom elit politycznych obniża się.

Polityk to również partia, której z reguły jest on członkiem, na tym polu również potrzeba działań PR. Tu ich podstawę stanowi dążenie do zdobycia wpływu na kształtowanie woli i świadomości politycznej obywateli po to by móc wpływać na życie społeczeństwa i zgodnie ze swymi celami budować podstawę swojego istnienia. Oznacza to, że partie nie mogą ograniczać działania wyłącznie do czasu kampanii, choć należy zauważyć, iż rozkład owych działań jest nieco inny ze względu na publiczność, do której są kierowane. W czasie kampanii wyborczej aktywność koncentruje się na silnym przekazie w stronę mediów, sponsorów i przede wszystkim tzw. niezdecydowanych grup wyborców, natomiast poza nią partie zwracają się głównie do swoich członków,

${ }^{16}$ Kampania wyborcza. Strategia..., dz. cyt., s. 114-116.

${ }^{17}$ Http:www.pressence.com.pl. 
zwolenników i szerokiej publiczności. Ta druga grupa docelowa pozwala zastosować względem siebie inne metody PR, takie jak gazeta partyjna, zjazdy partii, spotkania regionalne i w mniejszych grupach, a także obwieszczenia, komunikaty i doniesienia. Do szerokiej publiczności kierowane sa $\mathrm{z}$ reguly rozmaite informacyjne materiały drukowane, konferencje prasowe i komunikaty przekazywane na temat partii i jej działania za pośrednictwem mediów elektronicznych (telewizja, radio, internet $)^{18}$. Każda partia może wykorzystywać jeszcze inne techniki promocji siebie, może, a nawet musi wykorzystywać do tego swoich liderów i osoby cieszące się popularnością. Polskie partie wiedzą już, że piar jest często kluczowym działaniem, świadczyć może o tym chociażby niedawne zachowanie Sojuszu Lewicy Demokratycznej, który na krawędzi kryzysu pośpiesznie szukał nowej „twarzy”, osoby, która mogłaby zastapić skompromitowanego przewodniczącego i wnieść trochę świeżej energii w szeregi partii. Myślę, że pomysł z punktu widzenia public relations był bardzo dobry, choć odrobinę spóźniony. Mimo to w jakimś stopniu przedłużył życie partii, która bez wątpienia ma ostatnio kłopoty personalne, bowiem wielu z jej członków zamieszanych jest w różnorodne afery.

Moje krótkie rozważania nad potrzebą dobrego public relations $\mathrm{w}$ polityce nie wyczerpuja tematu, przede wszystkim ze względu na jego różne aspekty, które można by jeszcze poruszać i ich merytoryczna zawiłość. Moim celem nie było zagłębienie się we wszystkie przejawy piaru w polityce, a tym bardziej w ich dogłębną analizę. Chciałam jedynie wskazać możliwość zastosowania i ujęcia public relations w relacjach polityki i obywateli. Nie wyczerpałam również tematu możliwości zastosowania konkretnych środków PR, jest to celowe - pozostawiam to wyobraźni czytelnika, prawdopodobnie przyszłego politologa, doradcy politycznego.

Podsumowując: myślę, że argumenty, które przywołałam kategorycznie świadczą na rzecz potrzeby, konieczności stosowania i permanentnego istnienia PR w polityce, w naszej polskiej rzeczywistości, z zastosowaniem naszych metod i pomysłów. Jest to nieodzowne zjawisko dla wszystkich i rządzący, i rządzonych również tych, którzy nie mają o tym jeszcze zielonego pojęcia. PR nie tylko pomoże niektórym politykom wygrać wybory, ale także pozwoli zbudować społeczeństwo obywatelskie.

${ }^{18}$ K. Wojcik, dz. cyt., s. 783-784. 